\title{
Agrometeorological Indices Requirement of Wheat Crop at Allahabad Region under Different Sowing Environment
}

\author{
K.M. Praveen ${ }^{1 *}$, B. Mehera ${ }^{1}$, J. Naik ${ }^{2}$, Shweta Gautam ${ }^{1}$ and B.M. Madhu ${ }^{3}$ \\ ${ }^{1}$ Department of Environmental Science and NRM, College of forestry, SHUATS, \\ Allahabad-211007, Uttar Pradesh, India \\ ${ }^{2}$ Department of Agricultural-meteorology, OUAT, Bhubaneshwar, Orissa, India \\ ${ }^{3}$ Department of Soil Science and Agriculture Chemistry, SHUATS, Allahabad-211007, \\ Uttar Pradesh, India \\ *Corresponding author
}

\begin{tabular}{|l|}
\hline K e y w o r d s \\
$\begin{array}{l}\text { Growing degree days, } \\
\text { Heat use efficiency, } \\
\text { Thermal use efficiencies } \\
\text { and Bright use efficiency }\end{array}$ \\
\hline Article Info \\
\hline $\begin{array}{l}\text { Accepted: } \\
\text { 20 August 2018 } \\
\text { Available Online: } \\
\text { 10 September } 2018\end{array}$ \\
\hline
\end{tabular}

Wheat is a cereal grass of the Graminae (Poaceae) family, genus Triticum and is the world's largest cereal crop. It has been described as the 'King of Cereals' because of the acreage it occupies, high productivity and the prominent position it holds in the international food grain trade. World production of wheat was 757 metric tons which making it the second most-produced cereal after maize (FAO Stat, 2017). Wheat is the important food crop of the world it provides food to $36 \%$ of the global population
A field experiment was conducted during Rabi season 2016-17 at Farm Research Centre, College of Forestry, SHUATS, Allahabad to calculate agro-meteorological indices of wheat crop under three date of sowing i.e. $5^{\text {th }}$ November, $15^{\text {th }}$ November and $25^{\text {th }}$ November and three variety i.e. HD-2967, PBW-502, PBW-154. Wheat crop sown on $5^{\text {th }}$ November utilised more thermal and heat units as compared to $15^{\text {th }}$ November and $25^{\text {th }}$ November sown crops. The shortening of the duration of the crop sown late was due to forced maturity because of higher temperature during reproductive phase of the crop. Similarly Hygrothermal Unit-I and II was found highest at $5^{\text {th }}$ November followed by $15^{\text {th }}$ November. The heat use efficiency and temperature use efficiency was found highest for HD-2967 variety and lowest for PBW-154 variety.

\section{A B S T R A C T}

\section{Introduction}


time to attain the phenological stage is linearly related to temperature in the range between base temperature and optimum temperature. Heat and photoperiodic units are considered as the fundamental units used to examine the phenology of crops over climatic variations (Sreenivas et al., 2010). Heat use efficiency depicted that the heat utilized to produce one unit of plant biomass (Rajbongshi et al., 2016). Every crop has its own definite requirements for particular environmental conditions for its proper growth and yield (Razzaq et al., 1986). By keeping above facts in view an attempt has been made to study the agro-meteorological indices under different sowing dates to obtain higher grain yield of wheat.

\section{Materials and Methods}

Field experiment was conducted in the farm research centre, College of Forestry, Sam Higginbottom University of Agriculture, Technology and Sciences, Allahabad during rabi season (2016-17). Allahabad is located at $25.57^{\circ} \mathrm{N}$ latitude, $81.51^{\circ} \mathrm{E}$ longitude and 90 meter above the sea level. This region has Sub-tropical climate with extreme of summer and winter. The soil was sandy loam and slightly alkaline. The temperature falls down to as low as $1-2^{0} \mathrm{C}$ during winter season especially in the month of December and January. The Mercury rise up to $46^{\circ}-48^{\circ} \mathrm{C}$ during summer. The Allahabad receives the mean annual rainfall ranges $886 \mathrm{~mm}$. More than $70 \%$ rains are received during S-W monsoon season, 5-10\% rains are received in winter, $10-15 \%$ in pre-monsoon and 5-10\% during post monsoon season. Normal rainy days exceed 40 annually. Summer monsoon rainfall comes in down pours while winter rainfall comes in light drizzles and is easily absorbed in soils.

During crop season 2015-16, the morning relative humidity ranged between $82.43 \%$ to
$94.71 \%$ and the quantum of rainfall of $0.2 \mathrm{~mm}$ and that was received in $12^{\text {th }} \mathrm{SMW}$. The nine treatment combinations of the experiment comprised of three sowing dates viz. $5^{\text {th }}$ November $\left(\mathrm{D}_{1}\right), 15^{\text {th }}$ November $\left(\mathrm{D}_{2}\right)$ and $25^{\text {th }}$ November $\left(\mathrm{D}_{3}\right)$ and three cultivars HD2967 $\left(\mathrm{V}_{1}\right)$, PBW-502 $\left(\mathrm{V}_{2}\right)$ and PBW-154 $\left(\mathrm{V}_{3}\right)$ replicated thrice times in two factors RBD randomised block design. The treatment details are as follows $T_{1}=D_{1}+V_{1}, T_{2}=D_{1}+V_{2}$, $\mathrm{T}_{3}=\mathrm{D}_{1}+\mathrm{V}_{3}, \mathrm{~T}_{4}=\mathrm{D}_{2}+\mathrm{V}_{1}, \mathrm{~T}_{5}=\mathrm{D}_{2}+\mathrm{V}_{2}, \mathrm{~T}_{6}=\mathrm{D}_{2}+\mathrm{V}_{3}$, $\mathrm{T}_{7}=\mathrm{D}_{3}+\mathrm{V}_{1}, \mathrm{~T}_{8}=\mathrm{D}_{3}+\mathrm{V}_{2}$ and $\mathrm{T}_{9}=\mathrm{D}_{3}+\mathrm{V}_{3}$.

Data on weather parameters viz., maximum, minimum temperature, rainfall, bright sunshine hours, day length and relative humidity (RH) used for the study were recorded from meteorological observatory, College of Forestry, SHUATS, Allahabad.

The agrometeorological indices viz., GDD, PTU and HTU were calculated for different phenophases by adopting procedure laid out by Rajput (1980). For calculation of GDD, PTU and HTU base temperature was taken as $5^{\circ} \mathrm{C}$.

$\mathrm{GDD}=\sum\left[\left(\mathrm{T}_{\max } \cdot+\mathrm{T}_{\min .} \cdot\right) / 2-\mathrm{T}_{\mathrm{b}}\right]$,

Where, GDD $=$ Growing degree days, $\mathrm{T}_{\max }=$ Daily maximum temperature, $\mathrm{T}_{\min }=$ Daily minimum temperature and $\mathrm{T}_{\mathrm{b}}=$ Base temperature $5^{0} \mathrm{C}$ for wheat.

Heliothermal Unit (HTU) for particular phenophases of interest were determined according to the equation:

HTU $\left({ }^{\circ} \mathrm{C}\right.$ day hours $)=\sum($ GDD $x$ BSS $)$, Where, $\mathrm{BSS}=$ Bright sunshine hours (hrs).

Photothermal Unit (PTU) was calculated by using the following equation:

PTU $=$ GDD $\times \mathrm{N}$, Where, $\mathrm{L}=$ Maximum possible day length (hrs). 
Hygrothermal Unit (HgTU) was calculated twice in morning and afternoon by using the following equation:

HgTU = GDD x RH, where, $\mathrm{RH}=$ relative humidity in morning or afternoon (\%)

Heat use efficiency (HUE) for grain was obtained as:

$\mathrm{HUE}=\frac{\text { Total grain yield }}{\text { Accumulated GDD } \mathrm{Kg} / \mathrm{ha} /{ }^{0} \mathrm{C} / \text { day }}$

The Heliothermal Use Efficiency (HTUE) indicates the efficiency of crop to utilize the available bright sunshine hours.

HTUE $=\frac{\text { Total grain yield }}{\text { Accumulated HTU }} \mathrm{Kg} / \mathrm{ha} /{ }^{0} \mathrm{C} /$ day

The Photothermal Use Efficiency (PTUE) indicates the efficiency of crop to utilize the available maximum possible bright sunshine hours.

PTUE $=\frac{\text { Total grain yield }}{\text { Accumulated PTU }} \mathrm{Kg} / \mathrm{ha} /{ }^{0} \mathrm{C} /$ day

The Hygrothermal use efficiency ( $\mathrm{H}_{\mathrm{g}} \mathrm{TUE}$ ) indicates the efficiency of crop to utilize the available morning and afternoon relative humidity.

$\mathrm{H}_{\mathrm{g}} \mathrm{TUE}=\frac{\text { Total grain yield }}{\Delta \text { semmmlatad HoTIIF }} \mathrm{Kg} / \mathrm{ha} /{ }^{0} \mathrm{C} /$ day

The Maximum Temperature Use Efficiency ( $\left.\mathrm{T}_{\mathrm{MAX}} \mathrm{UE}\right)$ and Minimum Temperature Use Efficiency $\left(\mathrm{T}_{\mathrm{MIN}} \mathrm{UE}\right.$ ) indicates the efficiency of crop to utilizing the available maximum and minimum temperature respectively. However the Mean Temperature Use Efficiency $\left(\mathrm{T}_{\text {MEAN }} \mathrm{UE}\right)$ indicates the efficiency of crop to utilize the available mean temperature. This is also known as Actual Degree Day (ADD) because base temperature is not considered here.
$\mathrm{T}_{\mathrm{MAX}} \mathrm{UE}=$ Total grain yield Accumulated $\mathrm{T}_{\text {MAX }} \mathrm{Kg} / \mathrm{ha} /{ }^{0} \mathrm{C}$

$\mathrm{T}_{\mathrm{MIN}} \mathrm{UE}=$ Total grain yield

$\overline{\text { Accumulated } \mathrm{T}_{\text {MEAN }}} \mathrm{Kg} / \mathrm{ha} /{ }^{0} \mathrm{C}$

$\mathrm{T}_{\text {MEAN }} \mathrm{UE}=$ Total grain yield

Accumulated $\mathrm{T}_{\text {MEAN }} \mathrm{Kg} / \mathrm{ha} / /^{0} \mathrm{C}$

Bright Sunshine Use Efficiency (BSSUE) was calculated.

BSSUE $=$

Total grain yield

$\overline{\text { Accumulated Bright Sunshine hours }} \mathrm{Kg}$ /ha/hour

\section{Results and Discussion}

Meteorological condition for wheat crop during 2016-17

The weekly meteorological parameters observed during wheat growth and developmental was presented in the Figure 1. The weekly average maximum and minimum temperatures (Tmax and Tmin) varied between $19.46^{\circ} \mathrm{C}-37.7^{\circ} \mathrm{C}$ and $8.7^{\circ} \mathrm{C}-18.2^{\circ} \mathrm{C}$ respectively across seasons. The lowest minimum $\left(8.7^{\circ} \mathrm{C}\right)$ temperature received in $2^{\text {nd }}$ standard meteorological week of growing period.

The pan evaporation ranged from 1.89 to 3.55 mm week $^{-1}$ while the morning (RH-I) and afternoon relative humidity (RH-II) varied from $75 \%-94.8 \%$ and $33.5 \%-67.7 \%$ respectively. Bright sunshine hours also showed the large fluctuation from $45^{\text {th }}$ to $13^{\text {th }}$ standard metrological week. It achieved the lowest value during $49^{\text {th }}$ week $(0.69$ hours $)$ followed by $1^{\text {st }}$ week (1.8 hours) of growing period. 
Growing degree days and Heliothermal units

Results indicated that the number of days taken to attain various phenological stages varied with dates of sowing as well as due to variety (Table 1). Except at emergence stage when delayed sowing resulted in late emergence, all the stages attained under early sowing $\left(5^{\text {th }}\right.$ November) took more number of days in comparison to delayed sowing. All the stages showed similar pattern. The physiological maturity was maximum (127 days) under $5^{\text {th }}$ November sowing followed by 125.4 days under $15^{\text {th }}$ November and 123.1 days under $25^{\text {th }}$ November sowing. The early attainment of stages under delayed sowing was mainly due to higher temperature experienced by the crop under delayed sowing.

The accumulated thermal units requirement of wheat crop to attain different phenophases varied with sowing dates and varieties (Table $2)$. The crop sown on $5^{\text {th }}$ November $\left(D_{1}\right)$ accumulated more GDD (1960.65day $\left.{ }^{\circ} \mathrm{C}\right)$ to attain physiological maturity than $15^{\text {th }}$
November $\left(1899.45\right.$ day $\left.{ }^{\circ} \mathrm{C}\right)$ and $25^{\text {th }}$ November $\left(1822.65\right.$ day $\left.{ }^{\circ} \mathrm{C}\right)$ dates of sowing while regarding cultivars, little variation in thermal requirement was observed. The GDD accumulation was highest in $5^{\text {th }}$ November $\left(D_{1}\right)$ due to longer duration of crop growing period and lowest in $25^{\text {th }}$ November $\left(\mathrm{D}_{3}\right)$ sowing due to forced maturity caused by increase in temperature. Though the duration of physiological maturity under $25^{\text {th }}$ November sown crop was 4 days less than that attained under $5^{\text {th }}$ November.

This describes clearly the effect of temperature on phenological stage. Every crop needs a specific amount of GDD to enter its reproductive phase from vegetative phase. Early sowing resulted in absorbing sufficient GDD in relatively more time. While late sown crop experienced higher temperature during later stage in less time. Amarawat et al., (2013) also reported lower consumption of heat units under delayed sowing and they also stated that under late sowing high temperature conditions, the wheat crop completes its life cycle much faster than under normal temperature conditions, but yield less.

Table.1 Phenological development in growth duration of wheat as influenced by sowing time

\begin{tabular}{|c|c|c|c|c|c|c|c|}
\hline $\begin{array}{c}\text { Sowing } \\
\text { Dates }\end{array}$ & $\begin{array}{c}\mathbf{5 0 \%} \\
\text { Emergence }\end{array}$ & $\begin{array}{c}\mathbf{1 0 0 \%} \\
\text { Emergence }\end{array}$ & CRI & Heading & Flowering & Milking & $\begin{array}{c}\text { Physiological } \\
\text { Maturity }\end{array}$ \\
\hline $\mathbf{D}_{1}$ & 7.1 & 11.7 & 22.9 & 84.2 & 90.1 & 95.4 & 127 \\
\hline $\mathrm{D}_{2}$ & 6.5 & 10.7 & 22.3 & 80.3 & 85.3 & 90.8 & 125.4 \\
\hline $\mathbf{D}_{3}$ & 7.7 & 11.2 & 22.1 & 82.3 & 85.8 & 92.6 & 123.1 \\
\hline
\end{tabular}

Table.2 Grain yield and different heat units for wheat varieties under different sowing

\begin{tabular}{|c|c|c|c|c|c|c|}
\hline $\begin{array}{c}\text { Sowing } \\
\text { Dates }\end{array}$ & $\begin{array}{c}\text { Yield } \\
\text { (q/ha) }\end{array}$ & $\begin{array}{c}\text { GDD } \\
\left({ }^{\circ} \mathrm{C} \text { days }\right)\end{array}$ & $\begin{array}{c}\text { HTU } \\
\left({ }^{\circ} \text { day hrs }\right)\end{array}$ & $\begin{array}{c}\text { PTU } \\
\text { ( } \text { day hrs })\end{array}$ & $\begin{array}{c}\text { HgTU-I } \\
\left({ }^{\circ} \text { day hrs }\right)\end{array}$ & $\begin{array}{c}\text { HgTU-II } \\
\text { ('day hrs) }\end{array}$ \\
\hline $\mathbf{D}_{1}$ & 39.66 & 1960.65 & 11952.5 & 25916.7 & 174775.2 & 106560.2 \\
\hline $\mathbf{D}_{2}$ & 41.77 & 1899.45 & 11323.1 & 25011.7 & 167530.5 & 77533.47 \\
\hline $\mathbf{D}_{3}$ & 39.88 & 1822.65 & 9734.0 & 23931.7 & 162568.1 & 56074.97 \\
\hline
\end{tabular}


Table.3 Agro-meteorological efficiency index for wheat under different varieties

\begin{tabular}{|c|c|c|c|c|c|c|c|c|c|}
\hline Varieties & HUE & PTUE & HTUE & Hg $_{\mathrm{g}}$ TUE-I & HgTUE-II & $\mathrm{T}_{\text {MAX }} \mathrm{UE}$ & $\mathrm{T}_{\text {MIN }} \mathrm{UE}$ & $\mathrm{T}_{\text {MEAN UE }}$ & BSSUE \\
\hline$V_{1}$ & 2.2 & 0.153 & 0.33 & 0.015 & 0.037 & 1.44 & 2.98 & 2.04 & 6.59 \\
\hline$V_{2}$ & 2.19 & 0.167 & 0.40 & 0.024 & 0.053 & 1.41 & 2.92 & 2.0 & 6.49 \\
\hline$\overline{\mathbf{V}_{3}}$ & 2.02 & 0.165 & 0.36 & 0.021 & 0.072 & 1.36 & 2.80 & 1.94 & 6.13 \\
\hline
\end{tabular}

Fig.1 Weather parameters for wheat crop at Allahabad during 2016-17

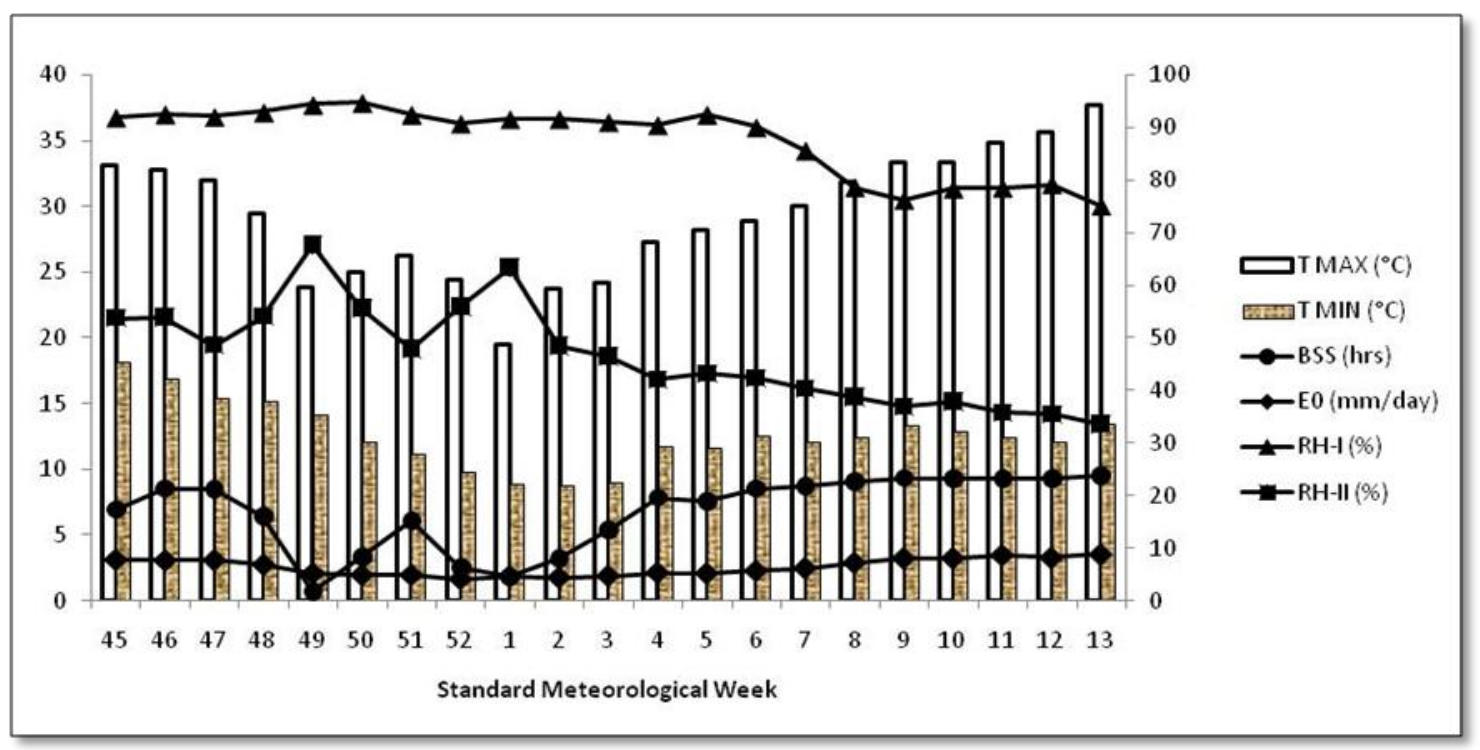

Similar results were obtained in case of HTU and PTU. As earlier sown wheat crop availed higher accumulated Heliothermal units (HTU), however, with delay in sowing HTU consumption deceased. At physiological maturity of wheat, accumulated HTU was $11952.5^{\circ}$ day $\mathrm{hrs}$ for $\mathrm{D}_{1}$ to reach maturity stage and followed by $\mathrm{D}_{2}\left(11323.1^{\circ}\right.$ day hrs $)$ and $\mathrm{D}_{3}\left(9734^{\circ}\right.$ day hrs). This might be due to the presence of cloudiness, lower temperature and lower sunshine hours for more days under timely sown condition in comparison to late sown crop. Similar results are reported by Chakravarty and Sastry (1983).

Crop sown on $5^{\text {th }}$ November required the maximum value of PTU $\left(25,916.7^{\circ}\right.$ day hrs $)$ for maturity as compared to other sowing dates. Moreover the Hygrothermal unit-I and II was highest for $\mathrm{D}_{1}$ followed by $\mathrm{D}_{2}$ and $\mathrm{D}_{3}$. Agro-meteorological efficiencies for

\section{different wheat varieties}

The different agro-meteorological efficiency of the wheat under different varieties has been given in Table 3. The heat use efficiency was highest in HD-2967 (V1) as $2.2 \mathrm{~kg} / \mathrm{ha} /{ }^{0} \mathrm{C} /$ day and lowest in PBW-154 (V3) as $2.02 \mathrm{~kg} / \mathrm{ha} /{ }^{0}$ $\mathrm{C} /$ day. Hence, it can be concluded that the timely sown HD-2967(V) had produced highest yield. HUE decreased with the delay in sowing. Similar results were reported by Paul and Sarker (2000), and Gill et al., (2014). The timely sown plants produced higher grain yield by using accumulated heat units efficiently as the temperature was favourable throughout growing period of crop. Therefore the plant will utilize more heat and increase physiological activities that results in higher grain yield. Similarly Amarawat et al., (2013) concluded that the lower HUE in delayed sowing can be 
expected due to accumulation of comparable GDD to that of early sowing at later crop growth stages. Since both maximum and minimum temperature remained higher during reproductive phase causing detrimental effect on dry matter accumulation. Moreover the value of $\mathrm{T}_{\mathrm{MAX}} \mathrm{UE}, \mathrm{T}_{\mathrm{MIN}} \mathrm{UE}, \mathrm{T}_{\mathrm{MEAN}} \mathrm{UE}$ was found highest in HD-2967 variety as 1.44, 2.98 and $2.04 \mathrm{~kg} / \mathrm{ha} /{ }^{0} \mathrm{C} /$ day respectively while lowest value was obtained in PBW-154 as 1.36, 2.8 and $1.94 \mathrm{~kg} / \mathrm{ha} /{ }^{0} \mathrm{C} /$ day. More the temperature use efficiency more will be the production of photosynthates by which the grain yield has increased. These results are in line with Haider et al., (2004). However, HTUE was highest in PBW-502 $\left(0.40 \mathrm{~kg} / \mathrm{ha} /{ }^{0}\right.$ day $\left.\mathrm{hrs}\right)$ followed by $\mathrm{PBW}-154$ $\left(0.36 \mathrm{~kg} / \mathrm{ha} /{ }^{0}\right.$ day hrs $)$ while PTUE was highest in PBW-502 $\left(0.167 \mathrm{~kg} / \mathrm{ha} /\right.$ degree ${ }^{0} \mathrm{C}$ day $)$ and lowest in HD-2967 (0.153 kg/ha/degree ${ }^{0} \mathrm{C}$ day). Similarly Hygrothermal use efficiency (HgTUE) I and II was found highest in PBW502 as 0.024 and in PBW-154 as 0.072 $\mathrm{kg} / \mathrm{ha} /{ }^{0}$ day \% respectively. The Bright Sun Shine use efficiency was highest in HD-2967 (6.59 hours/ day \%).) and followed by PBW502 (6.49 hours/day \%). The least Bright Sun Shine use efficiency was noticed by PBW154 (6.13 hours/day \%). From the above statement we can conclude that higher the Bright Sunshine use efficiency higher will be the yield. So, we can conclude that the variety HD-2967 sown on $15^{\text {th }}$ November has performed well rather than all other varieties sown on other sowing dates as for as meteorological efficiencies concerned.

The air temperature at different phenophases such as milking stage, grain filling stage and grain developing stage have greater effect on yield. Maximum GDD was accumulated in first date of sowing ( $5^{\text {th }}$ November) which leads to maximum vegetative growth. In second date of sowing (15 $5^{\text {th }}$ November) accumulated GDD was optimum and yield was maximum. It was also observed that sowing conditions on different phenophases were optimum under second date of sowing $\left(15^{\text {th }}\right.$ November) that resulted maximum yield. In case of Agro-meteorological efficiencies like heat use efficiency, temperature use efficiency, heliothermal use efficiency, photothermal use efficiency, hygrothermal use efficiency-I and II and bright sunshine use efficiencies are concerned, these are Maximum in the variety HD-2967 followed by PBW-502 and PBW154 respectively under Allahabad condition for 2016-17 Rabi season.

\section{References}

Amrawat, T., Solanki, N. S., Sharma, S. K., Jajoria, D. K and Dotaniya, M. K (2013). Phenology growth and yield of wheat in relation to Agrometeorological indices under different sowing dates. African J. of Agril Research, 8(49): 6366 -6374.

Chakravarty, N.V.K. and Sastry, P.S.N. (1983). Phenology and accumulated heat unit relationships in wheat under different planting dates in the Delhi regions. Agric. Sci. prog., 1: 32-42.

Gill, K. K., Babuta, R., Kaur, N., Kaur, P. And Sandhu, S. S. (2014). Thermal requirement of wheat crop in different agroclimatic regions of Punjab under climate change scenarios. Mausam, 65(3): 417-424.

Joshi, M. A., Faridullah, S. and Kumar, A. (2016). Effect of heat stress on crop phenology, yield and seed quality attributes of wheat. J. of Agrometeorology 18 (2): 206-215.

Mehta and Mattur (1979). Effect of different dates of sowing and nutrients on growth and yield of wheat cultivars. Agric. Sci. Digest., 21(2): 239-248.

Nuttonson, M.Y. (1955). Wheat-climatic relationships and the use of phenology in ascertaining the thermal and 
photothermal requirements of wheat. Washington, DC, American Institute of Crop Ecology.

Pandey, I.B., Pandey, R.K., Dwivedi, D.K. and Singh, R.S. (2010). Phenology, heat unit requirement and yield of wheat varieties under different crop growing environment.. Indian J. Agric. Sci., 80:136-140.

Patra, S. S., Mehera, B., Rout, S. and Kumar, R. (2016). Effect of hydropriming\& different sowing dates on growth and yield attributes of Wheat. J. of Applied and Natural Sci. 8 (2): 971 - 980.

Paul, N. K. and Sarker, D. K., (2000). Accumulated heat units and phenology relationships in wheat as influenced by sowing dates, Bangladesh J. Bot., 29: 49-54.

Rajbongshi, R., Neog, P., Sarma, P.K., Sarmah, K., Sarma, M.K., Sarma, D. and Hazarika, M. (2016). Thermal indices in relation to crop phenology and seed yield of pigeon pea (cajanus cajan L millsp.) grown in the north bank plains zone of Assam. Mausam, 67(2) 397-404.

Rajput, R.P. (1980). Response of soybean crop to climate and soil environments. Ph.D. Dissertation, IARI, New Delhi.

Razzaq, A., Shah, P., Khan, S.B., Saeed, K. and Mohammad, D. (1986). Effect of planting time on the growth and straw yield of wheat varieties. Sarhad $J$. Agric., 2: 327-334.

Shahzad. M. A, Wasi-ud-Din, Sahi. S. T, Khan. M. M, Aslam. M, Sanghi. A. H, Javed. S and Khalid. L (2002). Effect of sowing time on yield and yield components of wheat sown in st\&ing cotton. J. Agric. Res., 2002, 51(2).

Sreenivas, G., Reddy, M.D. and Reddy, D.R. (2010) Agro-meteorological indices in relation to phenology of aerobic rice. $J$. Agrometerol., 12(2): 241-244.

\section{How to cite this article:}

Praveen, K.M., B. Mehera, J. Naik, Shweta Gautam and Madhu, B.M. 2018. Agrometeorological Indices Requirement of Wheat Crop at Allahabad Region under Different Sowing Environment. Int.J.Curr.Microbiol.App.Sci. 7(09): 2986-2992. doi: https://doi.org/10.20546/ijcmas.2018.709.371 